\title{
DE LA ANTROPONIME LA NUME DE MĂNĂSTIRI
}

\author{
Silvia Pitiriciu \\ Universitatea din Craiova, România
}

\begin{abstract}
From anthroponyms to names of monasteries
Abstract: The names of certain monasteries in Romania were originally anthroponyms, common in the medieval period and still preserved nowadays. They also refer to names of hermits, monks, knezes, princes, and rulers, as well as high judges, high stewards, boyars, or people who donated land for the construction of monasteries. Some anthroponyms which underlie names of monasteries are in a relation of homonymy with toponyms (names of villages and communes), oikonyms (names of estates), and hydronyms (names of streams). Most onomastic units are secular names, less frequently monastic names. Once assigned to a monastery, a name acquires religious and cultural-historical fame.
\end{abstract}

Keywords: anthroponyms, monastery, continuity, medieval, onomastics.

\section{Introducere}

Sacrul și profanul sunt două valori existențiale asumate de umanitate din cele mai vechi timpuri. Ele constituie obiect de studiu al filosofiei, al religiei ori al literaturii. Problematica religiosului și a transcendenței implică sacralitatea, divinul. În lumea creștină, biserica marchează o treaptă înaltă de manifestare a sacrului. Prin rugăciune, omul se purifică şi se apropie mai mult de divinitate, spațiul bisericii devine sacru. Aceeași caracteristică o au și numele mănăstirilor, ca elemente aparținând unor entități sacre.

Mănăstirile din spaţiul românesc constituie un element de cultură și de înaltă spiritualitate. Ele sunt dovezi ale istoriei din cele mai vechi timpuri până în prezent. Prin ctitorii și slujitorii lor, mănăstirile au avut un rol important în susținerea și promovarea identității poporului român, au păstrat un tezaur literar-religios și cultural.

Când se dicută despre onomastica religioasă se au în vedere numele biblice, hagionimele.

Numele mănăstirilor constituie un element mai puțin studiat în lingvistica românească. Se cunosc unele contribuții în lexicologie (Bălan Mihailovici 2003, 2009), câteva abordări sociolingvistice privitoare la confesiuni (Oliviu Felecan 2010, 2013), în onomastică (Oliviu Felecan şi Nicolae Felecan 2013). Contribuția noastră se rezumă la rolul numelor comune și al toponimelor în fixarea numelor de mănăstiri (Pitiriciu 2017). Numele mănăstirilor se asociază în bună parte cu toponimele (oiconime, hidronime, oronime, odonime). Și antroponimele au un rol important în atribuirea 
numelor de mănăstiri. Cunoașterea modului cum au luat naștere mănăstirile și numele lor este importantă pentru înțelegerea faptelor istorice și religioase, a rolului acestora în cultura românească. De la fixarea locului, până la sfințirea mănăstirilor, faptele sunt condiționate de evenimente istorice și sociopolitice, motivate de întâmplări reale ori miraculoase. De-a lungul timpului, crearea locaşurilor sfinte implică participarea tuturor categoriilor sociale, de la voievozi și domnitori, la boieri de diferite ranguri, răzeși, cler și mireni, toți animați de credința în Dumnezeu.

Pentru a observa implicarea antroponimelor în atribuirea numelor de mănăstiri, am selectat din Ghidului mănăstirilor din România (Ciocoi et al. 2015) și din Lista mănăstirilor din România (https://ro.wikipedia.org) 35 de nume de mănăstiri ortodoxe, în mare parte, de pe întreg teritoriul țării, diferențiate în funcție de clasa socială a ctitorilor. Demersul de analiză are ca punct de plecare numele de mănăstiri, cărora li se explică numele prin antroponim. Etimologia are un rol în argumentarea antroponimelor și a numelor de mănăstiri. Nu mai puțin importante am considerat câteva date sumare legate de timpul și de ctitorirea lăcașurilor sfinte.

\section{Ctitorii voievodale și domnești}

Mănăstirea Bogdana, mun. Rădăuți (SV) și mănăstirea Bogdănești, sat Bogdănești (SV) îşi leagă numele de Bogdan I, voievod al Maramureșului (1330-1342 și 13551359) și domnitor al Moldovei (1363-1367). La origine, prenumele Bogdan are semnificația „dat de Dumnezeu” format din bog „Dumnezeu” și dan „dat” (Graur 1965: 37); este atestat în anul 1349 în Transilvania și în anul 1392 în Moldova (Tomescu 2001: 73).

În semn de mulțumire adusă lui Dumnezeu pentru victoria în luptele purtate, pentru a pune bazele unui stat liber și independent la răsărit de Carpați, Bogdan I, întemeietorul statului feudal moldovean, a ctitorit mănăstirea Bogdana, în a doua jumătate a secolului al XIV-lea. Aceasta a primit numele Bogdana, adică „a lui Bogdan” (Eșanu, Eșanu 2009). Înconjurat de moldoveni și de cler, la sosirea din Maramureș, Bogdan I se stabilește în târgul Baia și devine proprietar pe moșia cu satul Bogdănești, o așezare de vechi răzeși , „În amintirea descălecării lui, domnitorul și soția sa, doamna Maria, ridică Schitul Bogdănești numit și Bogoslovul, o biserică domnească și loc de rugăciune, în jurul anului 1363" (Mănăstirea Bogdănești, http://www.crestinortodox.ro/biserici-manastiri/manastirea-bogdanesti-67890.html).

Aroneanu, sat Aroneanu (IS), este ctitorită în anul 1594 de domnitorul Aron Vodă (1591-1592, 1592-1595). Mai înainte de zidirea acestei mănăstiri, pe același loc, se crede că exista o altă biserică, Mănăstirea grecească din țarina Iaşilor, zidită de Alexandru Lăpușneanu, tatăl lui Aron Vodă, în a doua sa domnie (Biserica Sfântul Nicolae-Aroneanu, http://www.crestinortodox.ro/biserici-manastiri/biserica-sfantul-nicolae-aroneanu-124077.html).

Mihai Vodă, București, este o mănăstire ctitorită de domnitorul Mihai Viteazul, în anul 1594. „Amplasată pe vârful dealului din faţa Podului Mihai Vodă, construcția a fost ridicată pe locul unei bisericuțe din secolul al XV-lea" (Grigore Ionescu 1938: 
210) de către Vlad Dracul, „conform unor documente din 1696” (Greceanu 1929: 154). Complexul mănăstirii a suferit mai multe transformări de-a lungul timpului, îndeplinind diferite funcții: „reședință domnească, spital militar, şcoală de medicină, Arhivele Statului” (Mănăstirea Mihai Vodă, https://ro.wikipedia.org/ wiki/M\%C4\%83n\%C4\%83stirea_Mihai_Vod\%C4\%83).

Într-o cronică nenumită, construirea mănăstirii Mihai Vodă are și o legendă, care spune că între anii 1589 și1591, Mihai Vodă este prins din porunca lui Alexandru-Vodă cel Rău, pe motiv că ar fi uneltit pentru a ajunge la domnie. „În timp ce este dus spre locul decapitării, Mihai se oprește la Biserica Albă Postăvari și se închină la icoana Sfântului Nicolae. Face un legământ să construiască o mănăstire pe dealul din apropiere, dacă scapă cu viață din această întâmplare. În final, după o garanție depusă de 12 boieri, Mihai este eliberat și își îndeplinește promisiunea, construind mănăstirea" (Tița-Mircea 2006: 5).

Negru Vodă, com. Cetățeni (AG), este ctitorită în anul 1215, de către Radu Negru Vodă. Mai apoi, „a fost rezidită de Basarab I și de fiul său, Nicolae Alexandru. Aceasta va fi reclădită de Matei Basarab, când devine și mănăstire" (Mănăstirea Negru Vodă, http://www.crestinortodox.ro/biserici-manastiri/manastirea-negru-voda-67819. html). La început, a purtat numele Schitul Cetăţuia Negru Vodă, fiind construită pe o stâncă înaltă, la altitudinea de 881 de metri, pe malul stâng al râului Dâmbovița. „Potrivit tradiției locale, pe culmea abruptă de piatră, a existat o cetate de rezistență din timpul ocupației romane. Cetatea ar fi fost loc de refugiu și pentru domnitorul Negru Vodă al Țării Românești, care avea aici și o peșteră de taină, Peștera lui Negru Vodă. De la această cetate și-ar fi luat numele, atât muntele, cât și satele din apropiere" (Mănăstirea Negru Vodă, http://www.crestinortodox.ro/biserici-manastiri/manastirea-cetatuianegru-voda-67995.html). Antroponimul Negru face parte din categoria „numelor create prin transferul onomastic al unor nume commune de origine latină” (Tomescu 2001: 72).

Bârsana, com. Bârsana (MM), este atestată în anul 1326, când cneazul Stanislau Bârsan primește moșia Bârsana „prin actul emis de regele Carol Robert. Mai târziu, în anul 1390, așa cum reiese din diplomele emise de regele Sigismund de Luxemburg, proprietarii moșiei Bârsana erau voievozii Bâlcu și fratele său, Drag” (Mănăstirea Bârsana, http://www.crestinortodox.ro/biserici-manastiri/manastirea-barsana-67952.html). Buni creștini, voievozii Bâlcu și Drag înzestrează mănăstirea cu terenuri arabile, fânețe, păduri și alte bunuri. Treptat, averile mănăstirii au crescut, dar a sporit și prestigiul mănăstirii ca vatră de spiritualitate românească. Aici se pregăteau preoți, cantori, zugravi. $\mathrm{Cu}$ toate interdictiile impuse de regimurile străine, mănăstirea Bârsana ținea legătura cu marile centre ortodoxe din Țara Românească și din Moldova, de unde se procurau cărți de slujbă și de învățătură.

Lupșa, com. Lupșa $(\mathrm{AB})$ este ridicată de „boierul Stanislav, descendent din familia cneazului Cândea de Lupșa, în anul 1421” (Mănăstirea Lupșa, http://www. crestinortodox.ro/biserici-manastiri/mitropolia-clujului-albei-crisanei-maramuresului/manastirea-lupsa-68072.html). Viața monahală a durat până în anul 1820, când, 
din cauza presiunilor antiortodoxe, mănăstirea a fost desființată, iar călugării au fost alungați de autoritățile habsburgice. Biserica a fost folosită de greco-catolici, până în anul 1948, când a revenit ortodocșilor.

\section{Ctitorii boierești}

Marii boieri (cunoscuți și sub numele de boieri veliți sau divaniți) erau proprietarii unor moșii întinse, dețineau dregătorii importante în administrație. Sunt cunoscute familii de boieri precum: Goleștii, Bălenii, Brâncovenii, Bălăcenii și Cantacuzinii (Șerban 1969: 5). Pe lângă aceștia, câțiva logofeți, vornici, postelnici etc. devin ctitori de mănăstiri.

Brâncoveni, com. Brâncoveni (OT), este construită de boierii Brâncoveni în secolul al XV-lea, ca loc de refugiu. Începuturile vieții monahale de la Brâncoveni se pierd în veacurile îndepărtate ale istoriei. „Comuna Brâncoveni este atestată documentar încă din timpul domnitorului Mircea cel Bătrân (1386-1418). Pe harta stolnicului Constantin Cantacuzino, în care este desenată Țara Românească, la începutul secolului al XVII-lea, satul Brâncoveni apare menționat ca târg și resedință a fostului județ Romanați” (Mănăstirea Brâncoveni, http://www.crestinortodox.ro/biserici-manastiri/manastirea-brancoveni-67808.html).

Familia boierească a Brâncovenilor descindea din neamul Basarabești. În secolul al XVII-lea, cel mai important reprezentant al familiei este Preda Brâncoveanu, personaj apropiat și nepot al voievodului Matei Basarab. Preda a deținut mari dregătorii şi a fost stăpânul unor moșii considerabile, care i-au revenit moștenire nepotului său Constantin Brâncoveanu, voievod al țării peste 25 de ani, mazilit și decapitat cu fiii săi la Istanbul în 1714. „Familia Brâncoveanu a început să se impună pe plan politic, militar și diplomatic de pe vremea lui Mihai Viteazul, când membri ai ei erau prezenți în Divanul țării, pe câmpuri de luptă și în misiuni diplomatice" (Familia Brâncoveanu, https://ro.wikipedia.org/wiki/Familia_Br\%C3\%A2ncoveanu\#cite_note-serban5-1). La mănăstirea Brâncoveni sunt înmormântați mulți membri ai familiei. În timpul războiului turco-austriac (1716-1718), mănăstirea este parțial arsă. În perioada 1721-1727, este tranformată în cazarmă austriacă, „doamna Marica Brâncoveanu intervenind pe lângă împăratul habsburgic, pentru eliberarea ei” (Mănăstirea Brâncoveni - un aşezământ încărcat de istorie, https://doxologia.ro/locuri-sfinte/ manastirea-brancoveni-un-asezamant-incarcat-de-istorie-galerie-foto).

Golia, mun. Iași (IS), este ctitorită de marele logofăt Ioan Golia în secolul al XVIlea. Numele mănăstirii Golia apare pentru prima dată „,într-un act întărit de domnitorul Ieremia Movilă, în anul 1606, când lăcașul bisericesc este închinat mănăstirii Vatoped, din Sfântul Munte" (Mănăstirea Golia, http://wwww.crestinortodox.ro/biserici-manastiri/mitropolia-moldovei-bucovinei/manastirea-golia-68105).html). „În anul 1650, voievodul Vasile Lupu hotărăște transformarea aşezământului căzut în ruină. Rezidirea s-a făcut după concepția arhitecturală a vechii biserici și a fost terminată de fiul său, Ștefaniță Vodă, în 1660" (Istoria mănăstirii Golia, https://golia.mmb.ro/istoria-manastirii-golia). Astăzi mănăstirea Golia apare ca o puternică fortăreață medievală de 
apărare, cu ziduri şi turnuri de incintă, cu porți mari din metal și lemn. Biserica actuală reprezintă o îmbinare de stiluri, îndeosebi baroc și bizantin, fiind construită într-un moment de realizare a Renașterii târzii în Principatele Române.

Cernica, oraș Pantelimon (IF), este ctitorie a „marelui vornic Cernica Știrbei și a soției sale, doamna Chiajna, fiind atestată documentar încă din anul 1608, printr-un hrisov domnesc al lui Radu Vodă Șerban” (Argatu 1988; Mănăstirea Cernica, http:// www.crestinortodox.ro/biserici-manastiri/manastirea-cernica-67798.html). În acel an, vornicul Cernica reface un vechi schit, îl înzestrează cu pământuri, păduri și sate, pentru pomenirea neamului său.

Sămurcășești, com. Ciorogârla (IF), construită în anul 1808 de vornicul Constantin Samurcaşi, pe moșia sa. În secolul al XIX-lea, o parte din moșia Ciorogârla, aflată în proprietatea familiei Ciorogârleanu, a ajuns în stăpânirea vornicului Constantin Samurcaş, de la care și-a luat apoi numele de Samurcăşești „Vechea denumire Ciorogârla s-a păstrat, atât mănăstirea, cât și localitatea, care s-a dezvoltat și s-a extins în preajma ei, au purtat concomitent cele două nume" (Mănăstirea Samurcășești-Ciorogârla,17.02.2015, https://obiectivortodox.wordpress.com/2015/02/17/manastirea-samurcasesti-ciorogarla/). La scurt timp după zidirea mănăstirii, vornicul Constantin Samurcas, moare în anul 1825, fără a lăsa vreo întocmire pentru cârmuirea și întreținerea acesteia. „În anul 1847, clucerul Alexandru Samurcaș, fiu adoptiv al ctitorului, întocmește un testament prin care asigura mănăstirii vatra și pământul din jurul ei” (Mănăstirea SamurcășeștiCiorogârla,17.02.2015, https://obiectivortodox.wordpress.com/2015/02/17/ manastirea-samurcasesti-ciorogarla/).

Toflea, sat Toflea, com. Brăhășești (GL), este ridicată de vornicul Murgoci Tofle la sfârşitul secolului al XVI-lea sau în primii ani al secolului al XVII-lea. Un document domnesc arată că „în anul 1581 Toflea este ctitorită pe actualul teritoriu al comunei Brăhășești” (Mănăstirea Toflea, http://www.edj.ro/mnstirea-toflea).

Teodoreni, mun. Suceava (SV), este o mănăstire ctitorită în anul 1597 de postelnicul Teodor Movilă, fratele mai mare al domnitorului Ieremia Movilă (1595-1600, 1600-1606). Antroponimul Teodor, de la care a luat naștere numele mănăstirii, este un compus de origine greacă, având semnificația „darul lui Dumnezeu” (Tomescu 2001: 37). Mănăstirea, cunoscută și sub numele Todireni, este construită pe locul unei bisericuțe de lemn și înzestrată cu numeroase moșii și sate (Adâncata, Nagoreni, Grușevița), devenind una dintre cele mai bogate lăcașuri de cult din Moldova. Într-un document datat 19 decembrie 1611-31 august 1612, se menționează că „Toader Moghilă” i-a dat „tot avutul său și multe sate ce au fost dreptele lui ocine” (Academia Română 1954: 41).

Micii boieri, comiși, stolnici etc., care dețineau proprietăți funciare și poziții administrative mai puțin însemnate, sunt, deopotrivă, ctitori de mănăstiri.

Cămărășeasca, oraș Târgu Cărbunești (GJ), este construită în jurul anului 1780 și reinființată în anul 1994. Ctitoria boierilor gorjeni Cămărășescu, așezată pe malul drept al râului Gilort, „a servit întotdeauna drept cetate de apărare contra cotropitorilor şi ca loc de refugiu al boierilor, atunci când regiunea era atacată de turci și de haiduci” 
(Mănăstirea Cămărășeasca, http://www.crestinortodox.ro/biserici-manastiri/manastirea-camaraseasca-122678.html). Numele Cămărășescu este un derivat format de la cămăraș (Graur 1965: 114).

Hadâmbu, sat Schitul Hadâmbului, com. Mironeasa (IS), este întemeiată de boierul grec Iani Hadâmbul, în anul 1659. După unele documente domnești, voievodul Gheorghe Ghica (1658-1659) i-a dăruit boierului grec Iani Hadâmbul, fost chelar, un loc „în pădurea Iașilor, la Dealul Mare, pentru a construi o biserică” (Mitropolia Moldovei și Bucovinei 2000: 116). Așezământul monahal este un complex fortificat reprezentativ pentru arhitectura Moldovei din secolul al XVII-lea (Botoșăneanul, Livadaru 2009).

Morunglavu, sat Șerbănești, com. Ștefănești (VL), este zidită în anul 1746 de boierul Matei Morunglavu, „fiul diaconului Dumitrașcu, din moșia Știrbei, și de soția lui, jupânița Maria, din pricina faptului că nu au avut urmași” (Mănăstirea Morunglavu - Biserica Sfântul Apostol Matei, http://www.crestinortodox.ro/biserici-manastiri/ mitropolia-olteniei/manastirea-morunglavu-biserica-sfantul-apostol-matei-136273. html). Mănăstirea este un monument reprezentativ al veacului al XVIII-lea. Datorită fortificațiilor ei, a fost folosită adesea ca loc de refugiu. În anul 1821, în drum spre București, în incinta mănăstirii s-au adăpostit pandurii lui Tudor Vladimirescu.

Apostolache, com. Apostolache (PH), este „ridicată între anii 1645-1652, de comisul Apostolache și de soția lui, Voichița, pe moșia Măstănești” (Mănăstirea Apostolache, http://www.crestinortodox.ro/biserici-manastiri/manastirea-apostolache-135226.html). Ansamblul monahal este realizat în vremea domnitorului Matei Basarab, în jurul unui locaș de rugăciune zidit mai înainte de anul 1595.

Jitianu, sat Braniște, com. Podari (DJ), este ridicată în perioada 1654-1658. Mănăstirea datează de la sfârșitul secolului al XV-lea și începutul secolului al XVI-lea, fiind o ctitorie a boierilor Craiovești. Vechea biserică de lemn a fost ridicată de Mircea cel Bătrân, ca mulțumire a victoriei de la Rovine. Istoricul Nicolae Iorga, în Inscripții, consideră că adevăratul fondator al mănăstirii de la începutul secolului al XVI-lea, este stolnicul Jițianu. „Datorită poziției strategice pe care o avea mănăstirea, ea a fost înzestrată de banii craioveni: Radu Șerban Vodă, Șerban și Ștefan Cantacuzino, dar mai ales de Constantin Brâcoveanu" (Mănăstirea Jitianu, https://ro.wikipedia.org/ wiki/M\%C4\%83n\%C4\%83stirea_Jitianu).

Din clasa micii boierimi fac parte și persoane care dețin funcții militare (căpitan, sulițaș). De numele lor se leagă câteva mănăstiri.

Adam, sat Adam (GL), este ctitorită de căpitanul Adam la mijlocul secolului al XVII-lea. Adam este un nume din Vechiul Testament, nu are valoare hagiografică (Tomescu 2001: 27), semnificația lui în ebraică fiind „pământ roșu, lut” (Graur 1965: 28). „Prima aşezare monastică a fost întemeiată la mijlocul secolului al XVIlea, când un călugăr a arătat unui cioban înstărit din codrii acestor locuri o icoană a Maicii Domnului făcătoare de minuni, propunându-i să ridice aici un schit. Ciobanul, nu numai că nu a ezitat a-i împlini dorința, dar el însuși a devenit monah, ajutând la ridicarea unei bisericuțe din lemn. În anul 1630, turcii care au trecut pe aici cu 
prilejul unui război i-au dat foc, călugării găsindu-și refugiu în pădurile din apropiere. Căpitanul Vasile Adam, împreună cu frații săi Costi, Movilă și Dabija, în aceste locuri au construit mănăstirea din temelii” (Mănăstirea Adam, https://ro.wikipedia.org/ wiki/M\%C4\%83n\%C4\%83stirea_Adam).

Barbu, sat Leiculești, com. Tisău (BZ), este ridicată în perioada 1662-1669 de vel căpitanul Barbu Bădeanu. Numele Barbu are o origine controversată (Tomescu 2001: 24). Căpitanul este „ajutat de soția sa, jupâneasa Rada și de fiii lor, Hrizea, Radu, Jipa, Andronic, Neagoe și Badea” (Mănăstirea Barbu, http://www.crestinortodox.ro/ manastiri/manastirea-barbu-117512.html). În secolul al XVIII-lea, mănăstirea Barbu a devenit metoc al mănăstirii Văcărești, închinată Sfântului Mormânt de la Ierusalim.

Ciolpani, oraș Buhuși (BC), a fost ridicată de sulițaşul Ciolpan, care s-a și călugărit aici în vremea lui Petru Șchiopu. „Construcția s-a păstrat până în anul 1730. Teodosie Cantacuzino a zidit pe acel loc o bisericuță din lemn, care există și în prezent" (Mănăstirea Ciolpani, http://www.crestinortodox.ro/manastiri/manastireaciolpani-117741.html).

\section{Ctitorii monahale}

Clerul, prin reprezentanții săi (mitropoliți, mari ierarhi, monahi, preoți, călugări, pustnici) constituie o categorie bine reprezentată între ctitorii de mănăstiri.

Izvoru Miron, sat Românești, com. Tomești (TM), a fost „începută în anul 1912, la inițiativa lui Miron Cristea, și sfințită în anul 1931" (Izvoru Miron, http://www.crestinortodox.ro/manastiri/manastirea-izvorul-miron-118004.html).

Antim, București, ctitorită de marele ierarh Antim Ivireanul, a fost „ridicată în perioada 1713-1715, pe locul unde era o veche biserică de lemn" (Mănăstirea Antim, https://ro.wikipedia.org/wiki/M\%C4\%83n\%C4\%83stirea_Antim). Mitropolitul Antim Ivireanu, originar din Gruzia, ocupă un loc aparte în cultura românească, fiind unul dintre marii ierarhi cărturari, îndrumătorul tipografiilor din București, Snagov, Râmnic și Târgoviște. Numele Antim face parte din seria „formelor greco-bizantine calendaristice" (Tomescu 2001: 67).

Agafton, sat Agafton, com. Curtești (BT), are ca „întemeietor pe ieroschimonahul Agafton, care a ridicat aici, în jurul anului 1729, o biserică de lemn" (Agachi 2004: 27-34; Mănăstirea Agafton, http://www.crestinortodox.ro/manastiri/manastireaagafton-117624.html). „Numele Agaton provine din gr. Agathon” (Graur 1965: 50).

Bâldana, sat Bâldana (DB), poartă numele preotului care a zidit-o, Gheorghe Bâldănescu, între anii 1827 și 1831" (Mănăstirea Bâldana, https://ro.wikipedia.org/ wiki/M\%C4\%83n\%C4\%83stirea_B\%C3\%A2ldana).

Rafaila, sat Rafaila, com. Todirești (VS) a fost ridicată în secolul al XVI-lea de monahul Rafail, numit înainte Radu, fost arcaș în oastea lui Ștefan cel Mare. Într-un hrisov găsit la mănăstire, se spune că „după biruința de la Podul Înalt împotriva turcilor, în anul 1475, Ștefan cel Mare întâlnește în lunca Băltenilor, doi copii plângând, pentru că turcii le omorâseră părinții. Erau Radu și Irina Bălteanu, fiii unui pădurar. Drept mângâiere, marele Voievod, a dat fiecăruia câte o moșie. Pe Radu, Ștefan îl face 
mai târziu oștean vestit al lui, Radu Arcașu. După un timp, acesta renunță la ostășie și merge la mănăstirea Neamțului, unde se face călugăr cu numele de Rafail. Spre bătrânețe se retrage la moșia sa. Aici ridică o bisericuță din lemn, în anul 1531" (Mănăstirea Rafaila, http://episcopiahusilor.ro/manastirea-rafaila). Așezământul monahal este atestat documentar în anul 1599. Numele Rafail este echivalentul lui „Rafael, de origine ebraică” (Graur 1965: 49).

Pângăraţi, com. Pângărați (NT) poartă numele călugărului Pangratie, după mărturia istoricului Nicolae Iorga. „În anul 1460, acesta a ridicat prima biserică din lemn. Mai târziu, schitul este transformat în mănăstire, de voievodul Alexandru Lăpuşneanu" (Mănăstirea Pângăraţi, http://wwww.crestinortodox.ro/biserici-manastiri/manastireapangarati-67836.html). Numele Pangrati corespunde gr. Pankrates, cf. gr. pan „tot”, kratos „putere” (Graur 1965: 34).

Agapia, sat Agapia (NT) poartă numele cuviosului Agapie, care ar fi ridicat în secolul al XIV-lea, în această zonă a Neamțului o bisericuță din lemn. La originea numelui stă gr. agapi „dragoste creștină”. Numele acestui călugăr a fost preluat apoi și de munții care înconjoară mănăstirea, de pârâu și de așezarea din vale. „Ctitorul Mănăstirii Agapia din Vale sau Agapia Nouă este hatmanul Gavriil Coci, fratele domnitorului Vasile Lupu" (Mănăstirea Agapia Nouă, http://www.crestinortodox.ro/biserici-manastiri/manastirea-agapia-noua-67927.html).

Nicula, sat Nicula (CJ), poartă numele pusticului Nicolae, care în anul 1326 dă numele său pădurii, satului și mănăstirii. „Prima mărturie istorică ce atestă existența mănăstirii face trimitere la o biserică din lemn, în stil maramureșean, din anul 1552. Între 1712 și 1714 biserica se reînnoiește" (Mănăstirea Nicula, http://www.crestinortodox.ro/biserici-manastiri/manastirea-nicula-adormirea-maicii-domnului-20794. html).

Începând cu 15 februarie 1699, mănăstirea Nicula iese din anonimat, devenind unul dintre cele mai căutate locuri de pelerinaj. „Icoana Micii Domnului, pictată de preotul ortodox Luca din Iclod în anul 1681, avea să plângă timp de 26 de zile, ca o prevestire a tristelor evenimente ce vor avea loc în jurul anului 1700, atât pentru viața monahală, cât mai ales pentru întreaga ortodoxie românească din Transilvania" (Mănăstirea ortodoxă Adormirea Maicii Domnului Nicula, http://www.manastireanicula.ro/index.php?id=1\&category=istoric\&lang=ro).

Almaş, com. Gârcina (NT) este zidită pe locul unei mai vechi așezări monahale, din secolul al XV-lea, sub conducerea sihastrului Vasile Almaș. „Ctitorii sunt familia Vasile și Maria Almaș, ciobani din Țara Hațegului, ajunși aici din cauza asupririi conducătorilor maghiari din Transilvania, care îi forțau pe români să se convertească la calvinism. În anul 1659, fiind ajutat de țăranii răzeși, evlaviosul Vasile Almaș, construiește un paraclis din lemn”, ulterior se călugărește sub numele Vasile (Mănăstirea Almaș, http://www.crestinortodox.ro/biserici-manastiri/manastirea-almas-67872.html). 


\section{Ctitorii ale unor mireni}

Credincioși cu ocupații diverse, motivați de evenimente marcante din viața lor, contribuie la ridicarea unor mănăstiri.

Corlățeni, com. Pojorâta (SV), este ridicată de Constantin Corlățeanu, primar al localității Pojorâta. „În anul 1934, familia Corlățeanu, împreună cu câțiva credincioși din localitate, au construit un schit modest. Biserica va fi sfintiță de către mitropolitul Nectarie, din Cernăuți” (Mănăstirea Pojorâta-Corlățeni, http://www.crestinortodox. ro/biserici-manastiri/manastirea-pojorata-corlateni-141805.html).

Ianculești, sat Șoimari, com. Șoimari (PH), „înființată de doamnele Eleonora Ianculescu și Ecaterina Ianculescu, în amintirea părinților decedați. Ele donează un teren agricol și forestier Arhiepiscopiei Prahova și în anul 2005 mănăstirea devine funcțională” (Mănăstirea Ianculești, http://www.crestinortodox.ro/biserici-manastiri/manastirea-ianculesti-68013.html).

Suzana, com. Măneciu (PH), a fost ridicată în anul 1740 de o credincioasă din Săcele-Brașov, cu numele Suzana Arșicu. Schitul Suzana devine în anul 1840 Mănăstirea Suzana.

Zamfira, sat Zamfira, com. Lipănești $(\mathrm{PH})$ este construită în timpul domnitorului Nicolae Mavrocordat, între anii 1721 și 1743, „la iniţiativa Zamfirei Apostoli, văduva bogatului comerciant Manoil Apostoli. După moartea Zamfirei, sarcina terminării lucrărilor îi revine norei acesteia, Smaranda, fiica agăi Ion Bălăceanu și nepoata voievodului Șerban Cantacuzino” (Mănăstirea Zamfira, http://www.crestinortodox.ro/ biserici-manastiri/manastirea-zamfira-67942.html).

Dălhăuți, com. Cârligele (VN), ar fi luat ființă încă din secolul al XV-lea (perioada 1464-1469), „,când celor doi ciobani originari din Dobrogea, Anufie și Irapalie Dălhăuș, li s-a arătat Maica Domnului. Aceștia au înțeles că este bine să construiască o mănăstire. După ce s-au călugărit, au pus bazele așezământului monahal cu numele Dălhăuți (Mănăstirea Dălhăuți, http://www.crestinortodox.ro/biserici-manastiri/manastireadalhauti-96692.html). Satul omonim a fost întemeiat mai târziu, în anul 1615, după cum se menționează în documentele Arhivele Naționale din București.

\section{Concluzii}

Din cele prezentate, putem observa legătura strânsă dintre antroponime și numele mănăstirilor românești. În procesul denominației, prenumele sau numele ctitorului este transferat mănăstirii, în formă identică sau adaptată, prin derivare sufixală.

a. Numele sau prenumele ctitorului este identic cu numele mănăstirii: Cernica Știrbei $\rightarrow$ Cernica, Barbu Bădeanu $\rightarrow$ Barbu, Radu Negru Vodă $\rightarrow$ Negru Vodă, Iani Hadâmbu $\rightarrow H a d a ̂ m b u$, Matei Morunglavu $\rightarrow$ Morunglavu, (comisul) Apostolache $\rightarrow$ Apostolache, Vasile Adam $\rightarrow$ Adam, Vasile Almaș $\rightarrow$ Almaș, Miron Cristea $\rightarrow$ Miron, Antim Ivireanul $\rightarrow$ Antim, (ieroschimonahul) Agafton $\rightarrow$ Agafton, Suzana Arșicu $\rightarrow$ Suzana, Zamfira Apostoli $\rightarrow$ Zamfira. Când mai mulți membri ai familiei au un rol semnificativ în viața socială și politică, numele circulă sub formă de plural, cum 
este cazul familiei Brâncovenilor. Acest nume este transferat mănăstirii (Brâncoveni). În cazul numelor sinonimice (Mihai Viteazul sau Mihai Vodă), mănăstirea preia numele care include poziția socială, cu prestanță onomastică mai mare (Mihai Vodă).

b. Mănăstirea primește un nume cu formă adaptată (prin derivare sufixală, grafico-fonetic și morfematic): Aron Vodă $\rightarrow$ Aroneanu, Bogdan $\rightarrow$ Bogdănești, Teodor Movilă $\rightarrow$ Teodoreni, Constantin Samurcaşi $\rightarrow$ Samurcășești, Ciolpan $\rightarrow$ Ciolpani, Constantin Corlățeanu $\rightarrow$ Corlățeni, Eleonora și Ecaterina Ianculescu $\rightarrow$ Ianculești, Anufie și Irapalie Dălhăuș $\rightarrow$ Dălhăuți. Adaptarea numelor românești la forma genitivului slav este o caracteristică a antroponimiei medievale: Bogdan $\rightarrow$ Bogdana. Prin analogie, transformarea o suportă și nume de alte origini: ebraică (Rafail $\rightarrow$ Rafaila), greacă (Agapie $\rightarrow$ Agapia). Orientarea spre forma (mai apropiată) de feminin atinge și alte nume: Cămărășescu $\rightarrow$ Cămărășeasca, Nicolae $\rightarrow$ Nicula (cf. Nicola), Gheorghe Bâldănescu $\rightarrow$ Bâldana (cu eliminarea sufixului patronimic -escu). Transferul de la antroponim la numele mănăstirii presupune și modificări fonetico-grafice: Pangratie $\rightarrow$ Pângărați (cu pronunție populară).

Prezența toponimelor în structura antroponimului este caracteristică familiilor nobiliare din Transilvania. Stanislav este descendent din familia cneazului Cândea de Lupşa (supranume ereditar). Toponimul are un prestigiu mai mare, devenind numele mănăstirii (Lupșa). Numele mănăstirilor sunt prestigioase, cu atât mai mult cu cât sunt omonime cu oronimele, hidronimele, oiconimele (Agapia, Nicula).

Ridicate în perioada medievală și în cea ulterioară, instituțiile monahale au avut un rol important în viața politică românească. Puternice fortărețe de apărare împotriva cotropitorilor (Golia, Cămărășeasca), au servit ca loc de refugiu pentru domnitori și boieri (Negru Vodă, Morunglavu). Ctitorii lor, voievozi, domnitori, boieri, mitropoliți, călugări, mireni au susținut o intensă activitate culturală și educativă. Prin daniile lor (moșii, păduri, vii, terenuri, mori) s-a consolidat instituția bisericii pe teritoriul românesc (Bârsana, Teodoreni, Jitianu). Multe mănăstiri sunt construite în urma victoriilor purtate de domnitori în lupta împotriva dușmanilor. În Moldova, Bogdan I ctitorește două mănăstiri care îi poartă numele (Bogdana, Bogdănești). În Țara Românească, membrii familiei Brâncovenilor (ctitorii mănăstirii Brâncoveni), prezenți în Divanul Țării încă de pe vremea lui Mihai Viteazul, se impun pe plan politic, militar și diplomatic.

Mănăstirile devin o oază de spiritualitate românească, țin legătura între ele, precum și cu centrele ortodoxe străine (Bârsana), fiind reprezentative pentru arhitectura și cultura națională (Antim, Agapia). Odată cu apariţia mănăstirilor, creștinismul se răspândește mai repede pe întreg teritoriul românesc. Viața din mănăstiri este influențată de monahismul de la Muntele Athos, simbol al sacralității, și de cel din țările ortodoxe apropiate.

\section{Bibliografie}

Academia Română.1954. Documente privind istoria României, seria A, veaul. XVI-XVII, sec. XVII, vol. III.

Agachi, D. 2004. Un topos uitat - Schitul lui Agafton. Forum cultural 2 (13): 27-34. 
Argatu, C. 1988. Istoria sfintelor mănăstiri Cernica și Căldăruşani. București. Editura Institutului Biblic și de Misiune al Bisericii Ortodoxe.

Bălan Mihailovici, A. 2003. Dicționar onomastic creștin. București: Editura Minerva.

Bălan Mihailovici, A. 2009. Dicționar onomastic creștin: repere etimologice și martirologice, ediția a II-a. București: Editura Sophia.

Botoșăneanul, C., D. Livadaru,. 2009. Mănăstirea Hadâmbu - 350 de ani de istorie și spiritualitate. Iași: Editura Doxologia.

Ciocoi, Gh., A. Dragne, Ș. Tică, D. Vlad.2015. Ghidul mănăstirilor din România. București: Editura Sophia.

Constantinescu, I. 1970. România de la A la Z. Dicționar turistic. București: Editura Stadion.

Eșanu, A., V. Eșanu. 2009. Întemeierea Țării Moldovei. Voievozi din sec. al XIV-lea (abordări și interpretări noi). Limba română 9-10 (XIX). http://limbaromana.md/index.php?go=articole\&n=688 (accesat în iulie 2017).

Felecan, O. 2010. Monastic Names in the North-West of Transylvania A Sociolinguistic and Cultural Perspective. Transylvanian Review XIX, Supplement, Nr.3, Aspects of Confessional Diversity within the Romanian Space: 193-208.

Felecan, O. 2013. Denumiri ale lăcașurilor de cult din România. În Un excurs onomastic în spațiul public românesc actual, 165-182. Cluj-Napoca: Editura Mega, Editura Argonaut.

Felecan, O. și N. Felecan. 2013. Cultural and Linguistic Layers Embedded in Romanian Oikonyms Derived from Hagionyms. În Onoma 48 (2013): 89-107.

Graur, Al. 1965. Nume de persoane. București: Editura Științifică.

Greceanu, O.N. 1929. Bucureștii. București: Tipografia Cartea Medicală.

Ionescu, Grigore. 1938. Ghid istoric și artistic. București: Fundația pentru Literatură și Artă „Regele Carol II”.

Mitropolia Moldovei și Bucovinei. 2000. Pelerin în Iași. Iași: Editura Trinitas.

Pitiriciu, S. 2017. De la nume comune la numele de mănăstiri. În Debating Globalization. Identity, Nation and Dialogue. Language and Discourse, 308-314. Târgu-Mureș: Editura Arhipelag XXI Press.

Șerban, C. 1969. Constantin Brîncoveanu. București: Editura Tineretului.

Tița-Mircea, C. 2006. Biserica Mănăstirii Mihai Vodă. Monumentele Bucureștiului istoric. București: Editura ASA.

Tomescu, D. 2001. Numele de persoană la români. Perspectivă istorică. București: Editura Univers Enciclopedic.

\section{Surse}

Biserica Sfântul Nicolae-Aroneanu. http://www.crestinortodox.ro/biserici-manastiri/biserica-sfantul-nicolae-aroneanu-124077.html (accesat în iulie 2017).

Familia Brâncoveanu. https://ro.wikipedia.org/wiki/Familia_Br\%C3\%A2ncoveanu\#cite_ note-serban5-1(accesat în iulie 2017).

Istoria mănăstirii Golia.https://golia.mmb.ro/istoria-manastirii-golia (accesat în iulie 2017).

Izvoru Miron. http://www.crestinortodox.ro/manastiri/manastirea-izvorul-miron-118004. html (accesat în iulie 2017).

Mănăstirea Adam. https://ro.wikipedia.org/wiki/M\%C4\%83n\%C4\%83stirea_Adam (accesat în iunie 2017). 
Mănăstirea Agafton. http://www.crestinortodox.ro/manastiri/manastirea-agafton-117624. html (accesat în iunie 2017).

Mănăstirea Agapia Nouă. http://www.crestinortodox.ro/biserici-manastiri/manastirea-agapianoua-67927.html(accesat în iunie 2017).

Mănăstirea Almaș. http://www.crestinortodox.ro/biserici-manastiri/manastirea-almas-67872. html (accesat în iunie 2017).

Mănăstirea Antim. https://ro.wikipedia.org/wiki/M\%C4\%83n\%C4\%83stirea_Antim (accesat în iunie 2017).

Mănăstirea Apostolache. http://www.crestinortodox.ro/biserici-manastiri/manastirea-apostolache-135226.html (accesat în iunie 2017).

Mănăstirea Barbu. http://www.crestinortodox.ro/manastiri/manastirea-barbu-117512.html (accesat în iunie 2017).

Mănăstirea Bâldana. https://ro.wikipedia.org/wiki/M\%C4\%83n\%C4\%83stirea_B\%C3\%A2ldana (accesat în iunie 2017).

Mănăstirea Bârsana. http://www.crestinortodox.ro/biserici-manastiri/manastirea-barsana-7952.html (accesat în iunie 2017).

Mănăstirea Bogdănești. http://www.crestinortodox.ro/biserici-manastiri/manastirea-bogdanesti-67890.html(accesat în iunie 2017).

Mănăstirea Brâncoveni. http://www.crestinortodox.ro/biserici-manastiri/manastirea-brancoveni-67808.html (accesat în iunie 2017).

Mănăstirea Brâncoveni - un aşezământ încărcat de istorie. https://doxologia.ro/locuri-sfinte/ manastirea-brancoveni-un-asezamant-incarcat-de-istorie-galerie-foto(accesat în iunie 2017).

Mănăstirea Cămărășeasca. http://www.crestinortodox.ro/biserici-manastiri/manastirea-camaraseasca-122678.html (accesat în iunie 2017).

Mănăstirea Cernica. http://www.crestinortodox.ro/biserici-manastiri/manastirea-cernica-67798.html (accesat în iunie 2017).

Mănăstirea Ciolpani. http://www.crestinortodox.ro/manastiri/manastirea-ciolpani-117741. html (accesat în iunie 2017).

Mănăstirea Dălhăuți. http://www.crestinortodox.ro/biserici-manastiri/manastirea-dalhauti-96692.html (accesat în iunie 2017).

Mănăstirea Golia .http://www.crestinortodox.ro/biserici-manastiri/mitropolia-moldovei-bucovinei/manastirea-golia-68105.html (accesat în iunie 2017).

Mănăstirea Ianculești. http://www.crestinortodox.ro/biserici-manastiri/manastirea-ianculesti-68013.html) (accesat în iunie 2017).

Mănăstirea Jitianu. https://ro.wikipedia.org/wiki/M\%C4\%83n\%C4\%83stirea_Jitianu (accesat în iunie 2017).

Mănăstirea Lupșa. http://www.crestinortodox.ro/biserici-manastiri/mitropolia-clujului-albei-crisanei-maramuresului/manastirea-lupsa-68072.html (accesat în iunie 2017).

Mănăstirea Mihai Vodă. https://ro.wikipedia.org/wiki/M\%C4\%83n\%C4\%83stirea_Mihai_ Vod\%C4\%83 (accesat în iunie 2017).

Mănăstirea Morunglavu - Biserica Sfântul Apostol Matei. http://www.crestinortodox.ro/ biserici-manastiri/mitropolia-olteniei/manastirea-morunglavu-biserica-sfantul-apostol-matei-136273.html (accesat în iunie 2017).

Mănăstirea Negru Vodă. http://www.crestinortodox.ro/biserici-manastiri/manastirea-negru-voda-67819.html (accesat în iunie 2017). 
Mănăstirea Negru Vodă. http://www.crestinortodox.ro/biserici-manastiri/manastirea-cetatuia-negru-voda-67995.html (accesat în iunie 2017).

Mănăstirea Nicula. http://www.crestinortodox.ro/biserici-manastiri/manastirea-nicula-adormirea-maicii-domnului-120794.html (accesat în iunie 2017).

Mănăstirea ortodoxă Adormirea Maicii Domnului Nicula. http://www.manastireanicula.ro/ index.php?id=1\&category=istoric\&lang=ro (accesat în iunie 2017).

Mănăstirea Pângărați. http://www.crestinortodox.ro/biserici-manastiri/manastirea-pangarati-67836.html (accesat în iunie 2017).

Mănăstirea Pojorâta-Corlățeni. http://www.crestinortodox.ro/biserici-manastiri/ manastirea-pojorata-corlateni-141805.html (accesat în iunie 2017).

Mănăstirea Rafaila. http://episcopiahusilor.ro/manastirea-rafaila (accesat în iunie 2017).

Mănăstirea Samurcășești-Ciorogârla. https://obiectivortodox.wordpress.com/2015/02/17/ manastirea-samurcasesti-ciorogarla/ (accesat în iunie 2017).

Mănăstirea Teodoreni. https://ro.wikipedia.org/wiki/M\%C4\%83n\%C4\%83stirea_Teodoreni (accesat în iunie 2017).

Mănăstirea Toflea. http://www.edj.ro/mnstirea-toflea (accesat în iunie 2017).

Mănăstirea Zamfira. http://www.crestinortodox.ro/biserici-manastiri/manastirea-zamfira-67942.html (accesat în iunie 2017).

Samurcășești - mănăstirea hărniciei. http://www.crestinortodox.ro/biserici-manastiri/mitropolia-munteniei-dobrogei/samurcasesti-manastirea-harniciei-68116.html (accesat în iulie 2017). 